\title{
Ice Shelf Studies off Northern Ellesmere Island, Spring 1983
}

\author{
MARTIN O. JEFFRIES'
}

\begin{abstract}
In spring 1983 work on the ice shelves of northern Ellesmere Island was continued. A total of $55 \mathrm{~m}$ of $7.6 \mathrm{~cm}$ diameter ice core was obtained from 10 locations. The longest core of $31.79 \mathrm{~m}$ is composed of iced-firn and basement ice and can be divided into three distinct strata according to ice salinity. Oscillating strains in Ward Hunt Ice Shelf were measured with a wire strainmeter. It is suggested that the periodic calving of ice from Ward Hunt Ice Shelf might be related to the effects of the high frequency oscillation of 35s to 40s. Ice conditions along $150 \mathrm{~km}$ of coastline continue to change. Continued monitoring of the ice shelves and landfast ice is believed to be necessary in view of the offshore development in the Beaufort Sea.
\end{abstract}

Key words: Ward Hunt Ice Shelf, Milne Ice Shelf, ice cores, saline ice, strainmeter, coastal ice conditions

RÉSUMÉ. Le travail sur les plateaux de glace du nord d'île d'Ellesmere continua durant le printemps de 1983. Un total de $55 \mathrm{~m}$ de carottes de glace d'un diamètre de $7.6 \mathrm{~cm}$ fut prélevé à 10 sites. La carotte la plus longue $(31.79 \mathrm{~m})$ était composée de névé et de glace de fond et pouvait être divisée en trois strates distinctes selon la salinité de la glace. Des tensions oscillantes dans le plateau de glace Ward Hunt furent mesurées avec une jauge extensiométrique. L'auteur propose que le détachement de glaçons du plateau de glace Ward Hunt pourrait être relié aux effets d'une oscillation de haute fréquence variant entre $35 \mathrm{~s}$ et $40 \mathrm{~s}$. Les conditions glaciales le long d'une côte de $150 \mathrm{~km}$ ne cessant de changer. Le contrôle continu des plateaux de glace et de la banquise côtière semble être nécessaire en raison du développement au large des côtes dans la mer de Beaufort.

Mots clés: plateau de glace Ward Hunt, plateau de glace Milne, carottes glaciales, glace saline, jauge extensiométrique, conditions glaciales des côtes

Traduit pour le journal par Maurice Guibord.

\section{INTRODUCTION}

In spring 1982 fieldwork was undertaken on Ward Hunt Ice Shelf and in the surrounding area, the object being to improve the understanding of the evolution, structure, behaviour and origin of arctic ice shelves (Jeffries, 1982). The ice shelves of northern Ellesmere Island are the source of ice islands, which, having calved from the ice shelves, circulate in the Arctic Ocean, passing through the Beaufort Sea. The continued offshore development in the Beaufort Sea has created renewed interest in the ice shelves and ice islands, the latter posing a possible threat to offshore structures and operations. The object of the 1983 fieldwork was to continue the program begun in 1982, expanding the work to include further investigation of Ayles and Milne fiords.

The fieldwork program included the following: ice coring and snow sampling; ice shelf dynamics; observations of coastal ice conditions; rock sample collection; water sampling of stratified fiords and lakes. This paper will consider some observations and preliminary results of the first three activities.

\section{ICE CORING AND SNOW SAMPLING}

Hattersley-Smith (1958) described arctic ice shelf growth as the result of great thicknesses of sea ice forming and remaining fast off the coast. Upward growth of the ice shelf took place through snow accumulation, firn formation (iced-firn) and refreezing of meltwater at the upper surface (Marshall, 1955), and downward growth occurred through the freezing of seawater at the undersurface (Crary, 1960). The original sea ice is known as basement ice (Lyons and Leavitt, 1961), while a unique brackish basement ice was described by Lyons et al.
(1971). Re-entrant ice, added to the ice shelf front after an ice island calving, was studied by Ragle et al. (1964). These ice types, and their mode of formation have only been described for Ward Hunt Ice Shelf. They are undoubtedly also present in Milne Fiord, which contains Milne Ice Shelf. In addition to these ice types, it has been suggested that part of Milne Ice Shelf is composed of glacier ice derived from glacier tongues that once moved across Milne Fiord (Jeffries, 1982). Figure 1 illustrates the conical mounds of moraine typical of the glacier ice of Milne Ice Shelf.

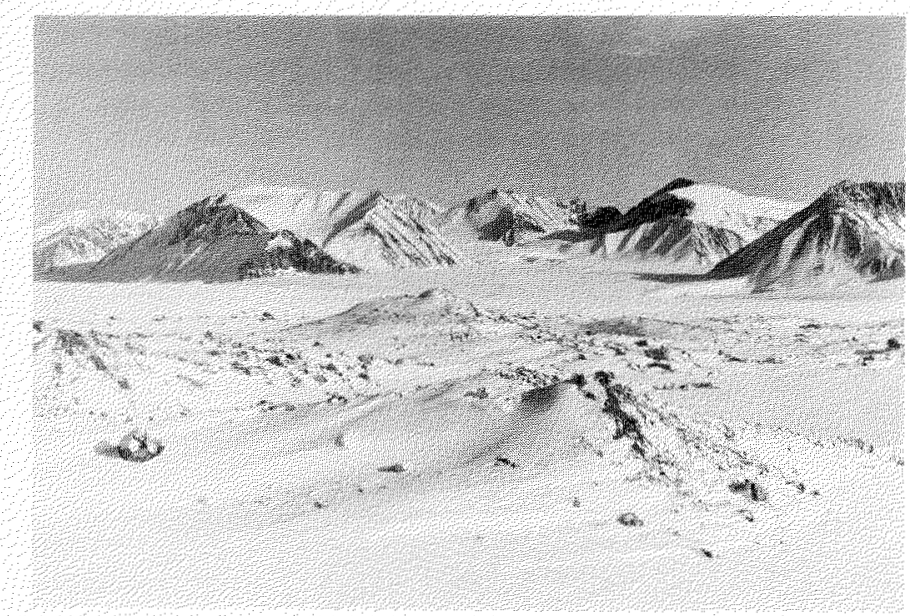

FIG. 1. Moraines on the surface of Milne lce Shelf. The cones of material are 3-5 $\mathrm{m}$ in height and are composed of locally derived schists, gneisses and quartzites from proterozoic/lower paleozoic units to the west of Milne Fiord (Trettin and Frisch, 1981).

In spring 1983 the ice coring program was designed to obtain as many of these ice types as possible. To that end a total 


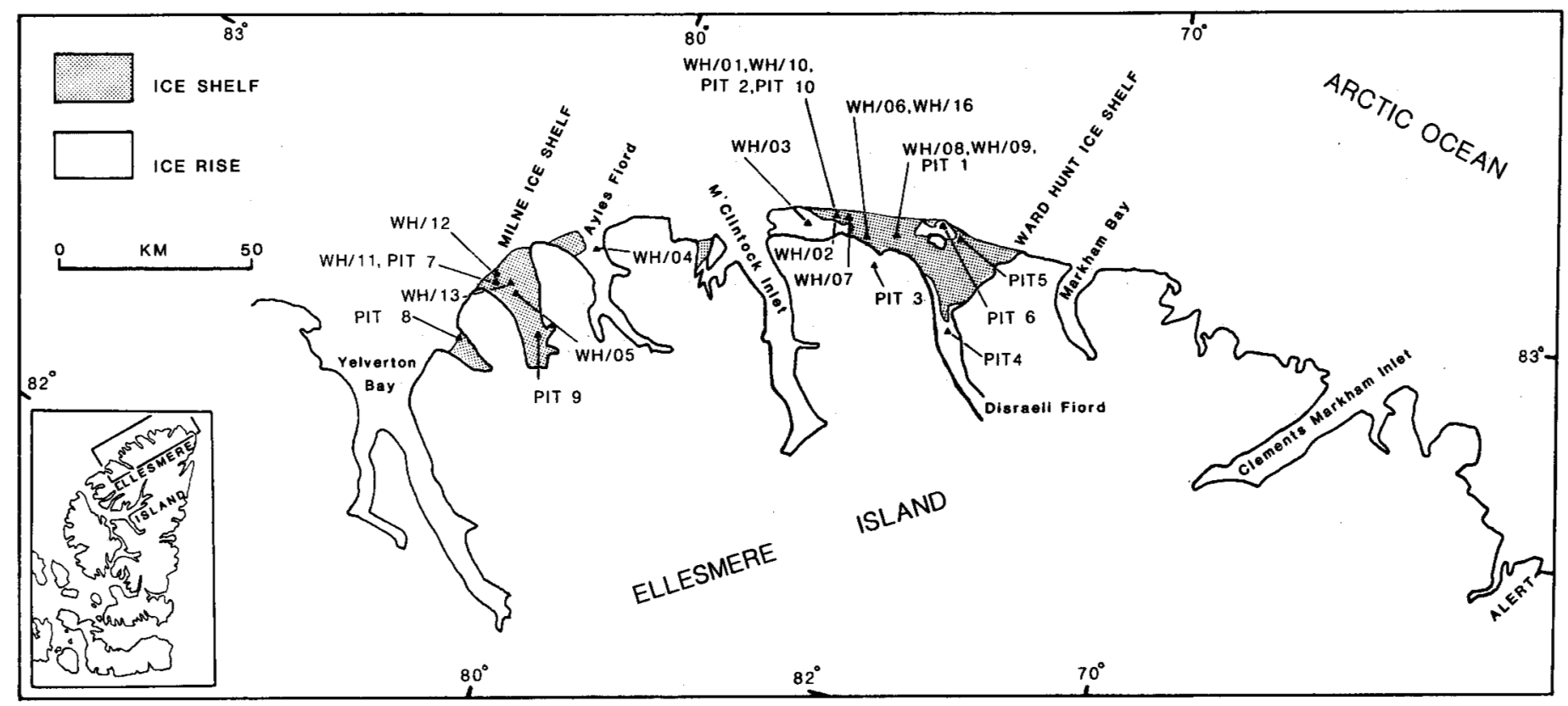

FIG. 2. Map of the north coast of Ellesmere Island and the area of study: Ward Hunt Ice Shelf to Milne Ice Shelf, with the location of ice cores and snow pits. Ice cores WH/01 to WH/07 were drilled in spring 1982 (Jeffries, 1982).

TABLE 1. Depth and location of ice cores

\begin{tabular}{|c|c|c|}
\hline Core & Location & Depth (m) \\
\hline WH/08 & $\begin{array}{l}\text { Ridge, } 20 \mathrm{~km} \text { E. of base camp, Ward Hunt } \\
\text { Ice Shelf }\end{array}$ & 31.79 \\
\hline WH/09 & $\begin{array}{l}\text { Trough, } 20 \mathrm{~km} \mathrm{E} \text {. of base camp, Ward Hunt } \\
\text { Ice Shelf }\end{array}$ & 2.16 \\
\hline $\mathrm{WH} / 10$ & Ridge, base camp & 5.00 \\
\hline WH/11 & Milne Ice Shelf re-entrant & 1.55 \\
\hline WH/12 & Milne Ice Shelf re-entrant & 2.05 \\
\hline WH/13 & Trough, outer unit of Milne Ice Shelf & 1.00 \\
\hline WH/14 & Ridge, central unit of Milne Ice Shelf & 2.00 \\
\hline WH/15 & Ridge, inner unit of Milne Ice Shelf & 1.90 \\
\hline \multirow[t]{2}{*}{ WH/16 } & Basement ice, Ward Hunt Ice Shelf & 2.06 \\
\hline & Disraeli Fiord & $\begin{array}{r}2.79 \\
55.00\end{array}$ \\
\hline
\end{tabular}

of $55 \mathrm{~m}$ of $7.6 \mathrm{~cm}$ diameter ice core, to complement the cores taken in 1982, was obtained from ten different locations along the northern coast of Ellesmere Island (Table 1; Fig. 2). The cores taken from troughs (WH/09 and WH/13) represent refrozen meltwater or lake water that accumulates in surface depressions during the ablation season. Cores $\mathrm{WH} / 11$ and $\mathrm{WH} / 12$ represent re-entrant ice from the NW part of Milne Ice Shelf. Jeffries (1982) described this area as "FLAT ICE" and unlike the remainder of the ice shelf; it is believed to be an area of ice regeneration after an ice island calving. The cores from ridges represent surface accumulation of iced-firn $(\mathrm{WH} / 10)$, glacier ice $(\mathrm{WH} / 14)$, and fiord ice $(\mathrm{WH} / 15)$. The latter is similar to the present-day ice cover on Disraeli Fiord. Ice core $\mathrm{WH} / 16$ is of basement ice.

The greatest effort was devoted to core WH/08. A total of $31.79 \mathrm{~m}$ of $7.6 \mathrm{~cm}$ diameter ice core was removed before drilling was discontinued; not only were cores being lost despite modifications to the core barrel, but there was the added possibility of losing the equipment in a brine-soaked hole. Salinity measurements undertaken in the field with an Endeco refracting salinometer (accuracy $\pm 0.1 \%$ ) revealed the stratified nature of the ice shelf at this location. It is noted that brine drainage from the ice might result in an underestimation of salinity values. Saline ice was first detected at a little over $14 \mathrm{~m}(4 \%$ at $14.56 \mathrm{~m})$; a maximum ice salinity of $16.9 \%$ occurred at $29.42 \mathrm{~m}$; brine-soaked ice chips from the bottom of the borehole had a salinity of $50 \%$. A plot of salinity versus depth (Fig. 3) shows three quite distinct layers evident in the ice shelf; $0-10 \mathrm{~m}$, negligible salinity; $10-26 \mathrm{~m}$, mean salinity of $2.30 \% ; 26-31.79 \mathrm{~m}$, mean salinity of $9.30 \%$. The upper $10 \mathrm{~m}$ is an accumulation of iced-firn while the saline ice is probably both basement ice and ice grown from bottom freezing. The very high salinities are probably due to soaking by underlying seawater.

Stable isotope (oxygen-18) measurements are being made on all the ice types in an attempt to characterize each according to its isotope signature and to further elucidate processes of formation (Jeffries, 1983). In the case of the accumulation of snow and firn at the ice shelf surface the oxygen- 18 variations can be altered considerably from the original precipitation values due to processes described by Koerner et al. (1973) for Meighen Ice Cap. In order to determine the stable isotope variations in present-day precipitation and to compare these with variations in the iced-firn, 10 snow pits were dug and snow samples obtained from locations along the coast (Fig. 2).

\section{ICE SHELF DYNAMICS}

The massive calving of ice from Ward Hunt Ice Shelf in 1961-62 (Hattersley-Smith, 1963) has been discussed in terms of the occurrence of a seismic event and unusually high tides, which might have created a critical condition in the ice shelf 


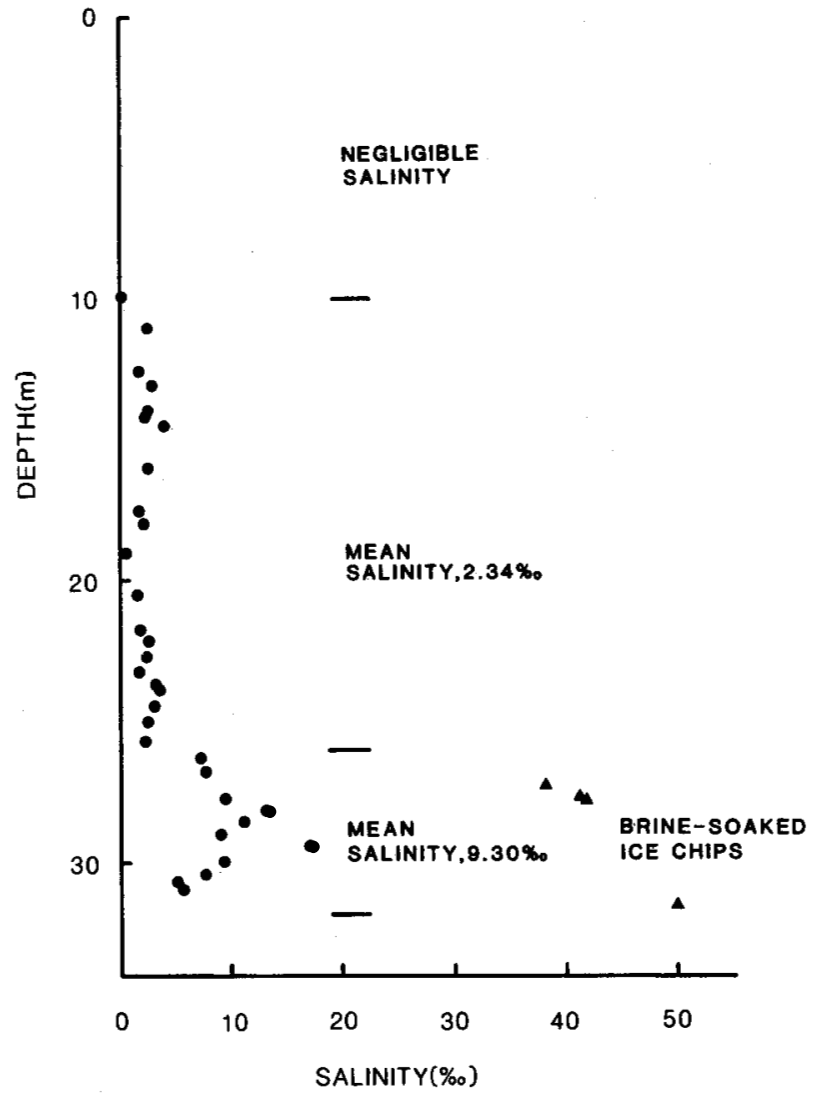

FIG. 3. Plot of salinity versus depth for ice core WH/08.

(Holdsworth, 1971). Although these events possibly contributed to the loss of almost $600 \mathrm{~km}^{2}$ of ice shelf, it is suggested that they do not wholly explain the calving mechanism. A floating ice mass acts as a filter of ocean wave energy. When a dominant frequency occurring in the incident wave spectrum coincides with one of the natural frequencies of the ice, then a resonant motion will occur. At relatively high modes of oscillation (vibration) sustained stresses may lead to crack propagation and fatigue failure in the ice (Holdsworth and Glynn, 1981). These authors propose such a vibration mechanism for the calving of tabular icebergs (ice islands) from ice shelves and glacier tongues. The vibrations, or oscillating strains, can be measured using wire strainmeters. A new instrument described by Moore and Wadhams (1981) was loaned by the Scott Polar Research Institute (Cambridge, U.K.) for a preliminary examination of oscillating strains in Ward Hunt Ice Shelf.

The strainmeter, installed at the west end of the ice shelf, registered three approximate cycles. The first was a $35 \mathrm{~s}-40 \mathrm{~s}$ period similar to that reported for ice island T-3 (e.g., Holdsworth and Traetteberg, 1974). This cycle is related to the ocean swell and is probably enhanced by the natural modes in the ice shelf (V. Squire, pers. comm.). The second, much longer period, was one of about 20 minutes. Keys (1978) notes a similar period for internal waves in Disraeli Fiord (Fig. 2). Since the main connection between Disraeli Fiord and the Arctic Ocean is believed to lie to the west of Ward Hunt Island (Crary, 1960), these tide-driven internal waves are expected to induce ice shelf movement also. Keys (1978) also recorded a 5.5-6 minute period in Disraeli Fiord that was noted on the strainmeter records and also on tiltmeter records for Ward Hunt Shelf in 1983 (Holdsworth, pers. comm.).

There appear to be three common oscillating strains in Ward Hunt Ice Shelf, one of which (35s-40s) might lead to calving and disintegration of the ice. Further consideration of these vibrations might explain the cyclic pattern of calving. It is suggested that the tidal and seismic events of 1962 served to increase and accelerate the effects of the normal vibrations leading to the massive calving of five ice islands.

\section{COASTAL ICE CONDITIONS}

The coastal ice between Ward Hunt Ice Shelf and Yelverton Bay (Fig. 2) consists mainly of shelf ice and multiyear landfast ice and is subject to considerable change due to calving and/or growth of ice. Beyond this coastal ice fringe lies the pack ice of the Arctic Ocean.

The most recent changes have occurred at Ward Hunt Ice Shelf (Fig. 2). Jeffries (1982) described the loss and/or grounding of $35-40 \mathrm{~km}^{2}$ of ice at the west end of the ice shelf. At some time during the summer or early fall of 1982 , a further $40 \mathrm{~km}^{2}$ of ice calved from the east end of the ice shelf (Jeffries and Serson, 1983). In spring 1982 there were considerable areas of multiyear ice attached to the western front of Ward Hunt Ice Shelf. In spring 1983 there were no signs of this ice, which most likely sheared off during summer 1982 .

The mouth of $M$ 'Clintock Inlet consists of a mass of multiyear landfast ice together with pieces of old shelf ice (recognized by numerous rocks and rock mounds on the ice surface). In 1983 the pressure ridge at the ice front was up to 5 $\mathrm{km}$ south of its 1982 position, suggesting a change here. At the west end of the mouth of $M^{\prime}$ 'Clintock Inlet there was a group of small (up to $0.05 \mathrm{~km}^{2}$ ) ice shelf fragments most likely derived from the most recent Ward Hunt calving.

Recent changes at the front of Ayles and Milne Ice shelves are to be described elsewhere in greater detail. However the following observations are noteworthy. The ice front across the mouth of Ayles Fiord is $2-5 \mathrm{~km}$ beyond that mapped in 1959. The fiord no longer contains a complete ice shelf; rather, part of the ice shelf has moved some distance out of the fiord, allowing the escape of another piece of ice shelf together with some icebergs created by the disintegration of an ice tongue. The mouth of the fiord is now blocked by both shelf ice and re-entrant ice, behind which lies $5 \mathrm{~m}$ thick fiord ice into which are locked scattered icebergs and small pieces of shelf ice.

While the ice front of Milne Ice Shelf remains the same as in 1982 , it is now believed that about $35 \mathrm{~km}^{2}$ of shelf ice calved from the northwest area of Milne Ice Shelf some time between 1959 and 1974. Since that time re-entrant ice has grown in place of the former ice shelf. This $9 \mathrm{~m}$ thick ice (J. Thorleifsson, pers. comm.) is considered to be a part of the ice shelf, not of the Arctic Ocean.

The bay to the south of Milne re-entrant, where snow pit 8 
was dug (Fig. 2), remains filled with an ice shelf beyond which there is a $5 \mathrm{~km}$ wide expanse of multiyear landfast ice that broadens farther across the mouth of Yelverton Bay.

\section{SUMMARY AND CONCLUSION}

During the period 23 April to 5 June 1983 a successful program of ice shelf studies was completed on the north coast of Ellesmere Island. As in 1982, the emphasis was on ice coring; a total of $55 \mathrm{~m}$ of $7.6 \mathrm{~cm}$ diameter ice core obtained by SIPRE hand corer will be the subject of chemical, isotopic and crystallographic investigations. The longest core, $31.79 \mathrm{~m}$, was composed of ice-firn/superimposed ice to a depth of $10 \mathrm{~m}$, below which the salinity values show the ice to be old sea ice.

The most recent massive calving of ice from Ward Hunt Ice Shelf (Hattersley-Smith, 1963) has been discussed in terms of the near coincidence of tidal and seismic events creating conditions in the ice shelf leading to fracture (Holdsworth, 1971). Undoubtedly this influenced the calving not only at Ward Hunt Ice Shelf but also at Milne and Ayles fiords. The calving might also have been related to vibrations within the ice. Strainmeter measurements revealed vibrations or oscillating strains with 35- to 40-second cycles, 5- to 6-minute cycles and 20-minute cycles. All these oscillations will exist in the water adjacent to and beneath the ice shelf.

Whereas Ward Hunt Ice Shelf has grown through a combination of sea ice thickening, surface accumulation and bottom freezing (Crary, 1960; Hattersley-Smith, 1958; Marshall, 1955), Milne Ice Shelf is believed to have a more complex structure and growth history. While the outer unit is probably similar in origin to Ward Hunt Ice Shelf, the central unit, constituting one-third of the total ice shelf area and covered with many moraines, is undoubtedly of glacier origin. The inner unit of the ice shelf is not well understood but the ice is similar to that on the surface of Disraeli Fiord. The Milne re-entrant offers an opportunity to study the growth of multiyear sea ice that might resemble the original thick sea ice basement from which most of the ice shelves were essentially created.

Changes to the ice along the north coast of Ellesmere Island continue. If the coastal ice conditions remain subject to sudden changes, closer monitoring of the ice ought to be considered. With continued offshore exploration and development in the Beaufort Sea and elsewhere the creation of new ice islands should be documented.

\section{Note added in proof}

The salinity and oxygen- 18 profiles of ice core $\mathrm{WH} / 08$ have now been analyzed and described in greater detail (Jeffries, 1985; Jeffries and Krouse, in press). Four distinct layers are now recognized in Ward Hunt Ice Shelf at the location of WH/08 with a freshwater, frazil ice-derived stratum at 18.90 $\mathrm{m}$ to $19.72 \mathrm{~m}$. This ice layer is sandwiched between layers of old sea ice.
PetroCanada; Supply and Services Canada, Contract No. 065B, 97708-1-0993 (through the Arctic Acoustics Section, Defence Research Establishment Pacific); Polar Continental Shelf Project; The Arctic Institute of North America and The University of Calgary. My thanks to Dr. S.A. Harris for reading the original manuscript, and also to Claudette Reed Upton and "anonymous" referees for their advice and suggestions for improvements. Special thanks to Harold Serson for his assistance and companionship in the field.

\section{REFERENCES}

CRARY, A.P. 1960. Arctic ice islands and ice shelf studies. Part II. Arctic 13:32-50.

HATTERSLEY-SMITH, G. 1958. Glaciological research in northern Ellesmere Island. Canadian Geographer 12:32-34.

1963. The Ward Hunt Ice Shelf: recent changes of the ice front. Journal of Glaciology 4:415-424.

HOLDSWORTH, G. 1971. Calving from Ward Hunt Ice Shelf, 1961-1962. Canadian Journal of Earth Sciences 8:299-305.

and GLYNN, J.E. 1981. A mechanism for the formation of large icebergs. Journal of Geophysical Research 86:3210-3222.

HOLDSWORTH, G., and TRAETTEBERG, A. 1974. Deformation of an Arctic ice island. Proceedings of the 2nd International Conference on Port and Ocean Engineering under Arctic Conditions, Iceland. 419-440.

JEFFRIES, M. 1982. The Ward Hunt Ice Shelf, Spring 1982. Arctic 35:542-544.

1983. Preliminary isotope studies on Ward Hunt Ice Shelf. Defence Research Establishment Pacific, Contractor's Report Series, 83-26. 56 p. 1985. Physical, chemical and isotopic investigations of Ward Hunt Ice Shelf and Milne Ice Shelf, Ellesmere Island, NWT. Ph.D. thesis. The University of Calgary. $310 \mathrm{p}$.

JEFFRIES, M.O., and SERSON, H. 1983. Recent changes at the front of Ward Hunt Ice Shelf, Ellesmere Island, NWT. Arctic 36:289-290.

JEFFRIES, M.O., and KROUSE, H.R. In press. Arctic ice shelf growth, fiord oceanography and climate. Zeitschrift für Gletscherkunde and Glazialgeologie 21 (1985).

KEYS, J.E. 1978. Water regime of Disraeli Fiord, Ellesmere Island. Defence Research Establishment Ottawa, Report No. 792.58 p.

KOERNER, R.M., PATERSON, W.S.B., and KROUSE, H.R. 1973. $\delta^{180}$ profile in ice formed between the equilibrium and firn lines. Nature 245: 137-140.

LYONS, J.B., and LEAVITT, F.G. 1961. Structural and Stratigraphic Studies on the Ward Hunt Ice Shelf. Bedford, Massachusetts, Geophysics Research Directorate, U.S. Air Force, Cambridge Research Laboratories. Final Report on Contract AF19 (604)-6188. 37 p.

LYONS, J.B., SAVIN, S.M., and TAMBURI, A.J. 1971. Basement ice, Ward Hunt Ice Shelf, Ellesmere Island, Canada. Journal of Glaciology 10:93-100.

MARSHALL, E.W. 1955. Structural and stratigraphic studies of the northern Ellesmere Ice Shelf. Arctic 8:109-114.

MOORE, S.C., and WADHAMS, P. 1981. Recent developments in strainmeter design. Scott Polar Research Institute, Sea Ice Group Report 81-2. A paper presented to the Workshop on Sea Ice Field Movement, St. John's, Newfoundland, April 29-May 1, 1980. 25 p.

RAGLE, R.H., BLAIR, R.G., and PERSSON, L.E. 1964. Ice core studies of Ward Hunt Ice Shelf, 1960. Journal of Glaciology 5:39-59.

TRETTIN, H.P., and FRISCH, T.O. 1981. Preliminary geological map and notes, Yelverton Inlet map-area, District of Franklin (NTS 340F, 540G). Geological Survey of Canada. Open File 758.

\section{ACKNOWLEDGMENTS}

This work was made possible by the generous financial and logistic support of the following: Dome Petroleum Ltd.; Gulf Canada Ltd.; 